no less evident in this. Chemists in general will be interested to learn that there are more than four thousand distinct literature references, many of them going back up to a hundred years; and, of these, nearly one-third are to American workers, and onequarter each to British and German.

In a treatise of this kind, some sort of selection has to be made from all the material available; and in such a selection everyone will be disappointed somewhere or other. In the section on molecules the account of molecular structure is quite good, though it. does not do sufficient justice to the concept of hybridization; but the account of molecular spectra is, by contrast, very thin, ionization potentials being scarcely mentioned and Rydberg series entirely omitted. In the same way there will be many who will regret that nothing is said about the concept of co-operative phenomena in the chapter on dielectrics.

Prof. Partington is most anxious that no one should fail to understand his analysis through insufficient knowledge of mathematics. So everything which is needed is fully developed. The result is uneven : there is the proof of the relation between the three moments of inertia for a plane lamina $\left(I_{x}+I_{y}=I_{z}\right)$; and there are also sixty solid pages of formulæ and analysis connected with spherical harmonics. Perhaps some of this latter may be used in later volumes : certainly not much of it was needed in this, and much of it is considerably more advanced than is the formula for moments of inertia.

When I had finished reading this book, I could not help wondering whether a task of this immensity is really possible for one person. For the subject-matter is too diverse for any person, however learned, however versatile, however patient-and Prof. Partington has all three of these qualities. It is inevitable that there should be mistakes. I found seven or eight quite serious ones, varying from the assertion that the spins of the two $3 s$ electrons in magnesium could be either parallel or anti-parallel, to the remark that under certain conditions the molecule $\mathrm{H}_{2}$ could be raised to a higher rotational level of $3 \cdot 54 \mathrm{eV}$. Quite apart from the lack of balance that was referred to earlier, these mistakes do detract from the reliability and trustworthiness of the book. I should not wish to let it fall into the hands of an unsuspecting undergraduate. But research students and intelligent undergraduates who have been forewarned will find it a mine of information, and will rejoice at the simple unaffected style and the sound historical feeling which are so evident within its pages.

C. A. Coulson microprojectors and other apparatus, and here and there suitable experiments, have appeared in journals devoted to science teaching. Prof. E. J. Hartung, professor of chemistry in the University of Melbourne, has now prepared a thorough and systematic account of the requisite apparatus, techniques and experiments.

He devotes his first six chapters as follows : general principles of projection optics ; description of equipment, including, among other items, light sources, cooling devices, lenses, mirrors, prisms, screens, projection microscopes, polarizing apparatus, diascopes and universal projectors; arrangement of the lecture room; and general notes on the actual technique of demonstration. The headings of his last eleven chapters are also those of the classes into which for convenience of treatment he has divided the two hundred and fifty experiments he describes. He gives full directions for carrying out each of these experiments and suggests the most suitable type of projection.

Experiments, notably those illustrating the Brownian movement, anisotropy and enantiotropy, lend themselves admirably to screen projection and, with economy of time, cannot be effectively shown to a large class in any other way. Prof. Hartung's selection includes many of the above class and, among other exceedingly good ones, some leading to an understanding of selective adsorption and illustrating differential flotation.

Mingled with these excellent illustrations are numerous simple reactions illustrative of elementary chemistry, such as the acidity of soda water, the interaction of carbon dioxide and lime water, the displacement of lead by zinc, the action of ammonia on copper salts, and so on, reactions which students can readily carry out by themselves, and which few teachers would call lecture experiments. I admit that by screen projection are revealed some phenomena, such as the streaming of invisible gases, which are not seen in the ordinary way of experimenting; nevertheless, I consider that the author has done his book a disservice by including so many experiments of the above class, for he thus makes his instruction entirely informative and gives no scope for the investigative spirit. Be that as it may, the teacher himself from the abundance herein given can select which experiments to screen, and all who desire to support their discourses with striking and berutiful illustrations should make themselves acquainted with this book.

G. FOWLES

\section{CHEMICAL LECTURE EXPERIMENTS BY SCREEN PROJECTION}

The Screen Projection of Chemical Experiments By Prof. E. J. Hartung. Pp. xiv + 291. (Melbourne : At the University Press; London: Cambridge University Press, 1953.) 30s. net.

HE literature of chemical lecture experiments is not extensive, and the addition to it of a book on a novel and special branch is welcome. Modern projection apparatus and technique permit smallscale experiments to be made easily visible to a class. A number of schools in Great Britain have for years used such aids, and descriptions of home-made

\section{OIL IN THE U.S.S.R.}

\section{Oil in the Soviet Union}

History-Geography-Problems. By Dr. Heinrich Hassmann. (Translated from the German with the addition of much new information by Alfred M. Leeston.) Pp. xvi +173 . (Princeton, N.J. : Princeton University Press ; London : Oxford University Press, 1953.) 3.75 dollars; $30 s$. net.

THE Russian way of life and the philosophy of Bolshevism may be enigmatical to Western peoples, but at least her economic and political activities in their external impacts may be scrutinized objectively ; in particular, her oil industry can be described and assessed at its present level. To comprehend past developments of the Russian petroleum industry and 